\title{
ROLE OF LOCAL LEADERSHIP IN PROVIDING QUALITY OF BASIC EDUCATION
}

\author{
(Study In Banyumas Regency)
}

\author{
Muslih Faozanudin (muslihfz@gmail.com) \\ (Public Administration Department, Faculty of Social and Political Sciences \\ Jenderal Soedirman University, Purwokerto-Central Java, Indonesia)
}

\begin{abstract}
Leadership is one of the important factors at the implementation of government decentralization especially for improving the quality of service to the local comunity. High commitment of local leadership will assure that the quality of service provision would be accomplished. The study examines how local leadership play role in providing quality of basic educational service. The results of the study showed that, the local leadership has not given enough attention to the provision of basic educational service yet.The commitment of local leader to provide the quality of basic educational service was still in average. This could be indicated that there were still many the facilities and infrastructuresofprimary public sector school, such as school library,textbook and scientific laboratory, have not met the standard, evensomeof them donot enough facilities and infrastructures.The study found that, when education was not the primary program of the local government leader, so it would not be the primary attention.
\end{abstract}

Key words: Local leadership, basic education.

\section{Background}

The policy of government reform, followed by decentralized of education system in Indonesia is a new hope for the reform in the provision of education service. It is expected that the quality of educational service would be better, because decission making competency among the actors of management of educataion at different level will more evenly distributed (Rado, 2010:37). Decentralization as an instrument for enhancing the quality of local service was likely not be implemented well in most local government in Indonesia. Most of them still have lack of capacities to implementing and executing program. Although the provision of educational services is the responsibility for all government level (centre, province, and local government), however, local government has more responsible for providing quality service, because of most financial budgets has been transfered to local goverment (Alisyahbana, 2010).

The experience of Banyumas regency, the decentralization of public primary education has also not influnced to the improvement of its quality of facilities and infrastructures. There have still many of public schools with bad condition of facilities and infrastrutures. In 2012, there were only 44.49 percent (from amount of 4.246 rooms) of teaching room that were feaseble for teaching activities. It is mean that more than fifteen perscent of rooms were ini not good (poor in quality). Other facilities such as school library were also the same condition. It were only 30 percentts of public primary schools that have meet the standard (Faozanudin, 21013). This condtion was in line with the Patrinos $(2007,1)$ statement, 'that public sector schools in most countries have limited resources to maintain school infrastructure and offer basic amenities for an appropriate learning environment'. The limitation of governemnt capacity in providing good service has great challenge to maintain an appropriate quality of education.

This phenomena was affected by the lack of comitment and attention from local leaders to education affair. Local leadership as epicentum of local developement has a strategic role for 
detemining quality and direction of organization destination (Zein, 1-4-2014). The task of leader is directing and cordinating ressources toward the accomplishment of organization goal (Sarundajang, 1999:215; Syafritz \& Russel, 1997:361). Therefore, the succes of local governement in delivering public service sector would be more depending on how the local leadership is carried out. High commitment of local leader, -not only in political mainstream but also in management- would influence to development and progress of local education. It is the fact that, until now, there are still many of local leaders who have not responsiveness toward the local problems. There were many local community services, including eduactional service, that have not been realized and executed well.

This paper is organized as follows. The first section provide an overview of the theoritcial basis of the role of local leadership ini providing the quality of basic education service; next section describes the result of the research; and be ended by conclussion

\section{Role Of Local Leadeship In Providing The Quality Of Basic Education Service}

Conceptually, leadership is the ability to influence the behavior of other people and also the internalization of values to others to achieve organization goals"(Leveriza, 1990:263, Vechio, 1995:65). The job of the leader of any organization is to get people to do thing they have never done before, to do thing that are not routine, and to take risk - and sometimes even to die - for the common good" (Shafritz and Russel, 1997:361). Therefore, leadership is the exercise of authority, in directing and commanding the work others. The job leaders are those who could simultaneously exercise of both kind of capacities. Therefore, leadership has important for organization for achieving organization goal. It will directing where organization will be steer. For most organization, the leader determines some polices and makes for crucial deccission, set work assigments for the follower and tends to direct where product oriented. When public organization is led by unqualified leader, it is lekely difficult for an organization to achieve its goal effectively, even for some cases it could reduce the community trust to government (Purbokusumo and Utomo, 2009:249).The succes of local leader when the leader value and combine some components i.e rule; management and development in organization (Makmur, 2002:40-41). According to Barnard (Shafritz \& Russel, 1997:363), the general function of leader or executive are: to provide a system of communication; to promote the securing of essential effort and to formulate and define the purpose and goals of an organization. The most critical function of leader is to establish and communicate a system of organziational values among organization mambers.

According to NPM Appraoch, the leader as manager should has a wide knowledege and capacity to role as facilitator for their follower. They should treat the follower and staff as colleague. Those capacities will worth to make more enviromentally conducive for staff working, where staff will devote their moral for achieving organizational goals (Lusthaus, 2002:64). The leader should also have the capacity to asses and interpret needs and opportunities outside organization to establish direction, to influence and to align others toward common aims, to motivate them and to make them responsible for their perfomance (Horton, et.all, 2003:24). In education speher, it is necessary for the leaderwho have not only above capacities, but the leadersshould havea good understanding about community demand for development, especially by giving wide 
oppurtunities forcommunity to access education easily. Its capability will reflectedby theircommitment to provide enough budget and feasible facilities and infrastcutures for educational process. The local leader should also have responsiveness to community problem which is refleted by their behavior to always defense public interest (Zen, 2014).

\section{Research Method}

This research employed a quantitative descriptive apparoach (Cresswell, 2009). Quantitatif data was collected through observation, interview and questionair. The research object was the head of elementary school which amount of 142, who chosen through proportional randam sampling from the 804 of pupulation. This procedure was employed with the reason that the population had homogenous characteristic. They had similar tasks and responsibilities. The collected data then analysed by descriptive model, such as cross-tab.

\section{4. Local Leaderhips On Educational Affairs In Banyumas}

The succces of local government to achieve its goal depends on whether the local leader has clear vision, and has a capacity to realized it. Local leader in this reseach comprises Bupati (as top of the local leader) and Head of educational office (operational leader). Bupati as local leader with his power and authority was demanded to have capacity to direct and infleunce the staff as followers to realizing his mision. It also should has the capacity of managing all activities related to his task and responsibility, and the head of educational office likewise. It has a responsibility to implement more operational of local educational policy. Thus, it has strategic role in supporting acomplishment of educational policy goal.

The result of the research showed that the capacity of the two leaders of Banyumas Regencies for achieving educational mission were in enough category, those were respectively only 62.6percent and 69.6 percent. Based on the responden perception, comparatively, the head of educational office was respectively assessed higher than Bupati. Detailed result of all indicators indicated the same trend. The commitment of the two leaders to local educational affairs were 59.3 percentand 66.6 percent; then incicator of clear mission of them were 64.7 percent and 69.9 percent; the extensive diferent was the responsivenss and the openess to staff development indicators with 63.4 percent and 70.6 percent; and 64.4 percent and 75.1 percent respectively. Fom those result, it could be said that,although the index category of two leaders was the same, there was a different perception of respondent related to their capacities, in which the head educational office was recognized better than Bupati. Detailed of those values are depictedin bellow table. 
Table: Score And Index Of Based On Leadership Indicators In Banyumas Regency

\begin{tabular}{|c|c|c|c|c|c|c|c|c|c|}
\hline \multirow{2}{*}{ No } & \multirow{2}{*}{ Question Item } & \multicolumn{5}{|c|}{ Score } & \multirow{2}{*}{ Value } & \multirow{2}{*}{ Index } & \multirow{2}{*}{ Category } \\
\hline & & 5 & 4 & 3 & 2 & 1 & & & \\
\hline \multicolumn{10}{|c|}{ Bupati Leadership } \\
\hline 1 & $\begin{array}{l}\text { Clear mission of } \\
\text { educational affair }\end{array}$ & 2 & 40 & 67 & 31 & 2 & 435 & 61.3 & Enough \\
\hline 2 & $\begin{array}{l}\text { Bupati Capacity to } \\
\text { direct mission }\end{array}$ & 1 & 55 & 63 & 22 & 1 & 459 & 64.7 & Enough \\
\hline 3 & Bupati Commitement & 0 & 31 & 78 & 30 & 3 & 421 & 59.3 & Enough \\
\hline 4 & $\begin{array}{l}\text { Ressponsivenes to } \\
\text { educational affair }\end{array}$ & 4 & 48 & 60 & 28 & 2 & 450 & 63.4 & Enough \\
\hline 5 & $\begin{array}{l}\text { Give free opportunity } \\
\text { to staff for opinion }\end{array}$ & 4 & 46 & 70 & 21 & 1 & 457 & 64.4 & Enough \\
\hline 6 & $\begin{array}{c}\text { Openess for receive } \\
\text { staff ideas }\end{array}$ & 9 & 30 & 74 & 20 & 9 & 436 & 61,4 & Sometimes \\
\hline \multicolumn{7}{|c|}{ Average Index } & 473.37 & 62.6 & Enough \\
\hline \multicolumn{10}{|c|}{ Head of Educational office Leadership } \\
\hline 1 & Clear mission & 8 & 61 & 62 & 1 & 0 & 492 & 69.3 & Clear \\
\hline 2 & $\begin{array}{c}\text { Capability to realize } \\
\text { mission }\end{array}$ & 3 & 57 & 66 & $\begin{array}{l}1 \\
6\end{array}$ & 0 & 473 & 66.6 & Enough \\
\hline 3 & $\begin{array}{l}\text { Commitment to } \\
\text { education affair }\end{array}$ & 5 & 46 & 82 & 9 & 0 & 473 & 66.6 & Enough \\
\hline 4 & $\begin{array}{c}\text { Capability to direct } \\
\text { staff }\end{array}$ & 7 & 63 & 62 & $\begin{array}{l}1 \\
0\end{array}$ & 0 & 493 & 69.4 & Enough \\
\hline 5 & $\begin{array}{l}\text { Openess to develop } \\
\text { staff capacity }\end{array}$ & 19 & 74 & 44 & 5 & 0 & 533 & 75.1 & Often \\
\hline 6 & $\begin{array}{l}\text { Responsiveness to } \\
\text { educational affairs }\end{array}$ & 9 & 68 & 54 & $\begin{array}{l}1 \\
1\end{array}$ & 0 & 501 & 70.6 & Responsive \\
\hline \multicolumn{7}{|c|}{ Average Index } & 494,2 & 69.6 & Enough \\
\hline
\end{tabular}


The result of the research showed that what was done by head office was more aknowleged by most respondent. There wes no clear mission and the lack of commitment of the leaders,however, has influenced to educational progress in Banyumas. This implies that how important the local leaders and the head of educational have a high comitment to achieve local government mission, especially for making progress of local education.The top of local leaders who cares about their responsibilities, they would always give more atentionsand devote their power authority to achieve their defined goal. They also would choose and employ a person who does not only dedicate and is loyal to them, but also has managerial and professional capacities in educational affairs (Zein, 2014). Clear misson of the leadercould essentially be used as a guidline for realizing the program and as a mean for supporting staff morale in carring task (Makmur, 2002:38).

To acheive thier goal and mission, local leaders could not realize his mission without be supported by others. Therefore, they should have a capacity to empower staffs as follower, by convincing them that their tasks could be done well (Dressang, 2002:7, Gardiner in Haass, 2005). The succes of the leaders when he could pass and solve many complex problemsfall on local education (Soetrisno, 2001:84).

The openess to receive other ideas from another is the characteristic of success (Haass, 2005:138). This characteristic was usually actuated by some method, such as, by giving wide opportunities to staffs or subordinates to discuss the problem and making dialogue among staff and leader about new ideas or solving problems. This condition is not in line with the result of the research whichwas only enough (avarage) category. It means that Banyumas leaders have not fully opened to receive all ideas from others yet.

In conjuntion with the condition of primary educational facilities and infrastructures, it is the fact that the Banyumas local leaders have slightly careless to most primary school buildings in which some school buildings in some areas in Banyumas ware respectively slihgtly until fully damaged condition. Even, for some cases, because of the limited of budget, some primary public schools have to wait for almost 1 year to have new buildings. Therefore, some students studied in apprehensive place, like in open room or school terrace. The head of primary school was forced to find a way out to solve teaching process (Faozanudin, 2013).Moreover, school library,textbook and scientific laboratory, have also met the standard, even some of them have did not have an enough facilities and infrastructures. The study found that, when education was not the primary program of the local government leader, it is was likely would not become the primary attention.

\section{Conclusion}

Decentralization essentially gives opportunity for local government for promoting local education to be more advance. However, this could be achieved when the local a leader has high commitment and responsiveness to the local educational affairs. Commitment of the leader is reflected by his capacity to provide enough budget, facilities and infrastructures for local education. The leader always fights to make the provision of education service, espsecially primary education service, that could be provided. Morever, the leader responsivenes could be shown byits his attention to community affairs. The leader always make a better community service. However, to make excelent service, it is not easy. The leader could not work alone, because they need 
support from others. The excelent leaderswork together among supprting staffs, community elements and supported by enough resourcess. These componentsshould be collaborative in action

\section{References}

1) Creswell, John W.(2009) .Research Design: Qualitative, Quantitative and Mixed Methods Approaches.Third Edition, California: Sage Publication, Inc.

2) Dresang, Dennis L.(2002) .Public Personnel Management and Public Policy. Fourth Edition, New York: Longman.

3) Faozanudin,

Muslih.(2013).PengaruhKapasitasOrganisasiPem erintah DaerahTerhadapEfektivitasKebijakan PemenuhanStandar Minimum Sarana Dan PrasaranaPendidikanDasar Di Kabupaten Banyumas. Bandung: Universitas Padjadjaran

4) Haass, Richard N.(2005).The Bureaucratic Entrepreneur: Bagimana menjadi Birokrat yang Efektif Dalam Pemerintahan.Jakarta: Ina Publikatama

5) Horton, Douglas, et. all. (2003). Evaluating capacity development: experiences from researchand development organizations around the world. The Netherlands: International Service forNational Agricultural Research (ISNAR). Canada: International Development Research Centre(IDRC), the Netherlands: ACP-EU Technical Centre for Agricultural and Rural Cooperation (CTA).

6) Hulpia, Hester, Geert Davos, and Hilde Van Keer. (2010).The Influence of Distributed Leadership on Teachers' Organizational Commitment: A Multilevel Approach The Journal of Educational Research, 103, 40-52
7) Leveriza, Jose P.(1990).Public Administration: The Business of Government.Metro Manila: National Book Store Inc.

8) Lusthaus, Charless, et,.all.(2002). Organizational Aassessment. A framework for improving performance. Ottawa: Inter-American DevelopmentBank, WashingtonDC and International Development Research Centre.

9) Makmur.(2002). Visi Kepemimpinan dalam pemerintahan, Manajemen Pembangunan, XI(39), September, pp. 35-41.

10)Rado, Peter. (2010) .Governing Decentralized Education Systems: Systemic Change In South Eastern Europe. Local Government and Public Service Reform Initiative. Budapest: OpenSocietyFoundations

11)Sarundajang, S.H. (1999).Arus Balik Kekuasaan Pusat ke Daerah.Jakarta: Pustaka Sinar Harapan.

12)Shafritz, Jay M, and E.W Russel. (1997).Introducing Public Administration.New York: Longman

13)Soetrisno, Lukman.(2001). Upaya Menciptakan Pembangunan Berkelanjutan.Otonomi Daerah: Peluang dan Tantangan. Jakarta: Suara Pembaharuan

14)Treverton, Gregory F. (2005). Broadening Public Leadership in a Global World. In Robert Kligaard \& Paul C. Light, (eds.).High Performanace Government: Structure, Leadership, Incentives. Santra Monica: Rand.

15) Vechio, R. P. (1995). Organizational Behavior. Orlando: Harcourt Brace and Co.

16)Zein, Mohamad Abduh.(2014).Kepala Sekolah. Kompas Selasa, 1 April 